\title{
Inhalt, Vol. 10, No. 2, 1987
}

\section{Contents}

Impressum 60

Diehl, V.; Pfreundschuh, M.; Löffler, M. und Smith, K., Köln, Rühl, U., Berlin, Georgii, A., Hannover, Hiller, E. und Gerhartz, H., München

Therapiestudien der deutschen Hodgkin-Studiengruppe. - Zwi-schenergebnisse der

Studienprotokolle HD1 , HD2 und HD3... 62

Flechtner, H.; Queißer, W. und Heim, M. E. , Mannheim, Henß, H. und Arnold, H., Freiburg,

Fritze, D., Darmstadt, Herrmann, R. und Edler, L., Heidelberg, Fritsch, H., Weinheim, Fritz, M.,

Karlsruhe, Trux, F. A., Schweinfurt, Kabelitz, K., Homburg

5-Fluorouracil, 4-Epidoxorubicin und Mitomycin C (FEM)

Kombinationschemotherapie beim fortgeschrittenen Magen-

karzinom. - Eine Phase-II-Studie der «Chemotherapiegruppe

Gastrointestinaler Tumoren (CGT)» 67

Reiner, G.; Reiner, A.; Jakesz, R. undKolb, R., WienlÖsterreich

Wertigkeit der Schnellschnittuntersuchung zur intraoperativen

Beurteilung des axillären Lymphknotenbefalls beim Mamma-

karzinom 72

Geyer, H. und Braun, A., Freiburg

Kernrezeptoren in Östrogenrezeptor-negativen Tumoren mit

Progesteronrezeptoren 79

Brambs, H.-J.; Freund, U.; Bruggmoser, G. und

Wannenmacher, M., Freiburg

Kombinierte intraduktale und perkutane Radiotherapie bei

maligner Gallenwegsobstruktion mit anschließender protheti-

scher Versorgung 84

Hinweise für Autoren 89

Koschel, G.; Kaukel, E. und Hain, E., Hamburg

Chemotherapie des nicht-kleinzelligen Bronchialkarzinoms mit

Mitomycin C, Vindesin und Cisplatin. - Ergebnisse einer Phase-

П-Studie $\quad 90$

Kurzmitteilungen:

Ammon, A. und Graewe, T., Göttingen

Kasuistischer Beitrag zur immunzytochemischen Differential-

diagnostik von serösen Ergüssen und Zystenflüssigkeit 97

Baumgartner, G.; Horaczek, A.; Grunert, P.; Kitz, K. und Wunsch, M., WienlÖsterreich

Hyaluronidase als Zusatz zur zytostatischen Chemotherapie bei

Glioblastomen 100

Wander, H.-E.; Nagel, G. A. und Bönisch, E., Göttingen, 
Kleeberg, U. R., Hamburg, Gartner, E., Hildesheim,

Hartlapp, ]., Bonn, Scherpe, A., Stade

Megestrolazetat versus Medroxyprogesteronazetat in der

Behandlung metastasierender Mammakarzinome. - Zwischen-

bericht einer multizentrischen Phase-ПI-Studie 104

Informationen für die Klinik 107

Buchbesprechungen 108

Imprint 60

Diehl, V.; Pfreundschuh, M.; Löffler, M. and Smith, K., Cologne,

Rühl, U., Berlin, Georgii, A., Hanover, Hiller, E. and

Gerhartz, H., Munich

Clinical Trials of the German Hodgkin Study Group: Preliminary

Results oftheHD1, HD2, and HD3 Protocols 62

Flechtner, H.; Queißer, W. and Heim, M. E. , Mannheim, Henß, H. and Arnold, H., Freiburg,

Fritze, D., Darmstadt, Herrmann, R. and Edler, L., Heidelberg, Fritsch, H., Weinheim, Fritz, M.,

Karlsruhe, Trux, F. A., Schweinfurt, Kabelitz, K., Homburg

5-Fluorouracil, 4-Epidoxorubicin, and Mitomycin C (FEM)

Combination Chemotherapy for Advanced Gastric Carcinoma. -

A Phase- $\Pi$ Trial by the "Chemotherapiegruppe Gastrointestina

ler Tumoren (CGT)" 67

Reiner, G.; Reiner, A.; Jakesz, R. and Kolb, R., Vienna/Austria

Intraoperative Staging of Axillary Lymph Nodes in Breast

Cancer Using Frozen Section Technique 72

Geyer, H. and Braun, A., Freiburg

Nuclear Receptors in Estrogen Receptor-negative Tumors with

Progesterone Receptors

79

Brambs, H.-J.; Freund, U.; Bruggmoser, G. and

Wannenmacher, M. , Freiburg

Combined Intracavitary and Percutaneous Radiotherapy in

Malignant Bile Duct Obstruction and Additional Prosthetic

Insertion 84

Instructions for Authors 89

Koschel, G.; Kaukel, E. and Hain, E., Hamburg

Chemotherapy of Non-Small Cell Lung Cancer with Mitomycin

C, Vindesine and Cisplatin 90

Short Communications:

Ammon, A. and Graewe, T., Göttingen

Immunocytochemical Differential Diagnosis of Serous Effusions

and Cystic Fluids - a Case Study 97

Baumgartner, G.; Horaczek, A.; Grunert, P.; Kitz, K. and Wunsch, M., Vienna/Austria

Hyaluronidase as an Adjuvant in Cytostatic Chemotherapy of

Glioblastoma 100

Wander, H.-E.; Nagel, G. A. and Bönisch, E., Göttingen,

Kleeberg, U. R., Hamburg, Gartner, E., Hildesheim,

Hartlapp, J., Bonn, Scherpe, A., Stade

Megestrol Acetate versus Medroxyprogesterone Acetate in the 
Treatment of Metastasizing Carcinoma of the Breast 104

Clinical Information 107

Book Reviews 108

Bibliographischer Hinweis: Inhaltsverzeichnisse dieser Zeitschrift erscheinen regelmäßig in current contents ${ }^{\circledR}$ sowie in anderen bibliographischen Diensten. 